\title{
The Historical Influence of Classical Islam on Western Humanistic Education
}

\author{
Rena D. Dossett
}

\begin{abstract}
Significant evidence suggests that the roots of Western humanistic education can be traced to medieval Islamic scholasticism. This study is based on careful analysis of historical documents which reveals the connection between classical Islamic scholarship and the foundations of Western humanistic education, the impact of which is evident to this day. Classical Islamic influence on medieval European education focuses on the origins of Italian Renaissance humanism in terms of the studia humanitatis and the ars dictaminis, and the roots of scholasticism as seen through the contributions of Abu Walid Muhammad ibn Ahmad ibn Rushd, known to the Western world as Averroes. During the medieval period, our two great civilizations worked together in creating and maintaining academic learning for the mutual betterment of mankind. A discussion of the Islamic influence on Western humanistic education provides a common ground for creating a dialogue of mutual respect and for alleviating present ideological tensions between the Middle East and the West.
\end{abstract}

Index Terms - Comparative education, history of education, Islamic studies, medieval studies, middle ages, Middle East.

\section{INTRODUCTION}

A discussion of the Islamic influence on Western humanistic education and thought is a discourse pregnant with possibilities for creating a much-needed modern dialogue of mutual respect and for alleviating present ideological tensions between the Middle East and the West. Nowhere is this influence more profoundly evident than in the realm of education during the period from European Middle Ages to the Early Renaissance period, or its corollary, the Age of Classical Islam. It was during this time our two great civilizations worked together in creating and maintaining academic learning for the mutual betterment of mankind.

Significant evidence suggests that the roots of Western humanistic education can be traced to medieval Islamic scholasticism. Given the constraints of this paper, the Classical Islamic influence on medieval European education will be limited to an inquiry into the origins of Italian Renaissance humanism in terms of the studia humanitatis and the ars dictaminis, and the roots of scholasticism as seen through the contributions of Abu Walid Muhammad ibn Ahmad ibn Rushd, known to the Western world as Averroes. The timeline of discussion focuses on the Islamic Classical period, which roughly corresponds to the end of the Western Patristic era with the works of St. Augustine in

Manuscript received May 19, 2013; revised July 26, 2013.

Rena D. Dossett is with the Ball State University, USA (e-mail: rddossett@bsu.edu). the $6^{\text {th }}$ century AD to the cusp period between the death of scholasticism and rise of positivism beginning the West's early modern era around 1450 .

\section{SCHOLASTICISM}

The scholastic movement in the West began around the sixth century and was connected strongly to Christian education. The curriculum of these schools involved the seven liberal arts: the trivium composed of grammar, rhetoric, and logic and the quadrivium composed of geometry, arithmetic, music, and astronomy [1]. The golden age of scholastic philosophy actually occurred more around the thirteenth century when the study of dialectic and seven liberal arts had given way to the studia generalia, or university study. Scholasticism aimed to reconcile the patristic thought, predominately of St. Augustine, to new European Christianity [2]. Scholastics knew little of Aristotle, save his logic, and therefore focused on dialectical reasoning. This focus on the dialectic gave a new direction to Christian tradition in philosophy. Patristic philosophy's mystical, intuitive component was suppressed in favor of scholasticism's apparent emphasis on rationalism [1]. St. Thomas Aquinas, the greatest scholastic thinker of his age, reasoned that there are two distinct sciences: theology and philosophy. They are distinct, as philosophy relies on reason alone and theology uses truths derived from revelation; both must agree with one another, as God is the creator of all truths. The development of these principals is considered the crowning achievement of scholastic thinking [1]. The dependence on the dialectic method fostered an application of reason to matters of faith, so in the truest sense they were hardly rationalists.

Dialectic became the science of disputation, proof, and proposition. It focused on syllogism and was aimed at using language to prove certainty. This type of scholastic dialectical reasoning is attributed to Averroes, the medieval Arabic commentator on Aristotle [3]. Averroes, or more correctly, Ibn Rashd, is known for bringing the works of Aristotle to European education and his detailed commentaries on Aristotelian logic in particular. His influences can be strongly felt in writings of St. Thomas Aquinas and the scholastic movement as a whole [3]. It is also said the concept of natural law entered the western mind through the writings of Ibn Rashd, who explored this concept elaborately in his work Justice and Jihad, in which he discusses the human mind's capability of judging unlawfulness, as was posited earlier by Aristotle in Nicomachean Ethic and Rhetoric [3]. Ibn Rashd's use of the dialectic was purposeful and self-reflective. He describes the external technique and external form of the dialectic 
method as being "for the purpose of teaching beginners the method of disputation," but this was not the goal of the dialectic. Its goal rather was " $[\mathrm{t}]$ he use of reason in order to bring the content of the faith closer to the spirit of the thinking man, describe it as a system of clarifying the objections and difficulties" [4].

Much like St. Thomas Aquinas, Ibn Rashd desired harmony between faith and reason, as reason is seen as God's ultimate gift to man. Ibn Rashd described himself in the third person "as someone who has devoted himself to the study of the Ancients (meaning Greek philosophers) and who delights in the search for the truth while remaining religious and deeply committed to the religious laws of God" [5]. In this quote he echoes the words of another great scholar who would herald in the age of the early Renaissance, Desiderius Erasmus.

Ibn Rashd's works give us the foundations for early rationalist thought in medieval Europe. His over-arching sentiments startlingly parallel those of St. Thomas Aquinas in profound ways. Consider Ibn Rashd's value on reason:

- Reason is the most excellent of God's gifts to man. Being God's gift to Man, Reason's first fruits should be obedience to God in His commandments and His prohibitions. This means, of course, if God gave us Reason then Reason and Revelation are from the same source, and the two must be in harmony and cannot be in contradiction. Right reason is in harmony with Revelation except that which agrees with Reason [4].

Furthermore, Ibn Rashd warns of excessive affection for either "strict rationalism" or "strict traditionalism" in saying, "Nothing causes intellectuals to err except acts due to hastiness of temper and their being content with the Ancients to the exclusion of the Moderns" [4].

The focus on dialectic in Classical Islamic culture was not due exclusively to the intellectual and spiritual pursuits of philosophers such as Ibn Rashd. The Islamic intellectual scene at the time had a practical and much needed rhetorical use for dialectic - that being the legal use of rhetoric. Aristotle's concept of forensic oratory as "intended to provoke judgment on past action" [6] was fundamental to the development of the orthodoxy of Classical Islamic jurisprudence by virtue of Ibn Rashd [7]. Islamic jurisprudence had already been practicing a version of Abelard's Sic et Non as a means of disputation for centuries. Given Islamic orthodoxy's absence of hierarchical ruling councils, matters of jurisprudence depended upon a form of dialectic or logic to solve matters of disputation [7]. The dialectic was fundamental for the development of Islamic orthodoxy [8]. In the words of medieval scholar George Makdisi:

- While Muslim philosophers pursued the philosophy of Aristotle, Muslim 'jurisconsults', as such, were attracted to the dialectic as if by a magnet because of its role in advancing and perfecting ijma-khilaf, sic et non. Having no councils or synods, Islam had to depend on the principle of ijma, or consensus, to define orthodoxy. And since consensus could be tacit, the doctors of law, as a matter of conscience, felt obliged to make known their differences of opinion, lest a doctrine which they opposed be considered as having their tacit acceptance. Since there was no formal organization of ijma, the process worked retroactively. Each generation cast its glance backward to the generations that preceded it to see whether or not a certain doctrine had gained acceptance through consensus. In time the differences of opinion where compiled in large tomes and khilaf became an important field of knowledge taught in the schools of law [7].

The Classical Islamic obsession with jurisprudence was necessary in order to maintain the orthodoxy of the faith. This focus on legal matters within the context of religion led to the further development of the notion of "the license to teach and issue legal opinions," ijazat at-tadris wa l-ifta; this was a formal license granted by ninth century Islamic universities requiring four years of study in a guild school of law or madhhab (This is a corollary in some ways to the medieval Latin degree, licentia docendi.) The degree could be pursued further to culminate some ten years later in a doctorate of law degree or mudarris. Classical Islamic higher education only allotted for doctorial specialization that of doctorate of law, which functioned as "an individualistic Islamic doctorate created to provide machinery for the traditionalist determination of Islamic orthodoxy" [5].

As the university system in the European Middle Ages evolved to provide a secularizing influence on hierarchical Christianity, the Islamic university rose to prominence under the need to establish religious orthodoxy. The end result of a university education in the Christian West was recognized scholarship in a given area of expertise, whereas the end product of a university education in the Classical Islamic age was jurisdictional magisterium in which "the authentic teaching office of Sunni orthodoxy was in the hands of the professors of the religious law individually, in the legal opinion on the first level and in the consensus on second" [5]. A doctorate in theology in the Christian West was given only jurisdictional powers to determine, in a scholastic sense of the word, "those matters that are established by the Pope can be uncertain," ea quae condita sunt a papa possunt esse dubia [5].

\section{THE RISE OF HUMANISM}

Humanism rose as an intellectual movement in Europe during the late Middle Ages and Early Modern period. Francesco Petrarch of Italy, Rudolpho Agricola of Germany, and Desiderius Erasmus of Holland are considered early founders of humanistic thought in poetry and rhetoric. The goal of humanism was to train the individual man to write and speak well for the good of both his own moral development and society's as well. There was a focus on the "dignity and eloquence of Man" as developed through the study rhetoric, poetry, literature, and Latin classics [1]. A return to the classics and the classical learning of antiquity made humanism appear secular in contrast to the rigidity of the Church, and Man returned to be, in some sense, "the measure of all things."

The rise in Western humanism called for a revamping of the medieval curriculum, which focused on the scholastic obsession with dialectic and logic, as well as the completion of the liberal arts education (ars liberales) with the 
quadrivium of arithmetic, geometry, music, and astronomy as was preceded by the preparatory work completed in the trivium of grammar, dialectic, and rhetoric [9]. The studia humanitatis was the new curriculum innovation that called for disciplinary dedication to rhetoric, dialectic, classical literature, history, natural philosophy, and mathematics. The ars dictaminis provided an invaluable addition to the curriculum as practical application of rhetoric to the art of letter writing for business, law, and personal use [10]. The ars dictaminis was an extremely teachable device and uniquely applicable to a variety of disciplines serving the communication needs of European intellectuals throughout the Middle Ages [1].

What is often not discussed in our rhetorical history texts is the parallel between Western humanism and the Middle East's own version of the same. Islamic humanism began in the seventh century. In some respects, its development parallels the West's. There was a desire to return to classical language and learning. Makdisi writes:

- Humanism began when Muslims became aware of the every growing difference between the classical language of the sacred scriptures and the language that developed after they broke out of Arabia. Journeys back to their origins became a scholarly necessity. The Arab scholars recorded in notebooks the classical language spoken by the Arabians and collected preIslamic classical poetry among the various tribes, collecting them carefully to be used as evidential examples, clarifying what to them had become strange and rare words of the Koran and the Prophetic Traditions [11].

The humanist movement in Classical Islam developed out of philological concerns of language loss and involved a revitalization of grammar and lexicography. The movement would evolve to be characterized by two traits:

- First, the aim for eloquence in speech and literary composition emulating the classical Arabic models involving a complex selection of studies in the arts termed ulum al-adabiya, similar to the studia humanititatis, and secondly, the use of a method of dictation, al-Amali, which is required by the exigencies of classical Arabic [11].

The ulum al-adabiya curriculum of Classical Arabic scholarship is broken down accordingly:

1) Grammar (nahw) and lexicography (lugha)

2) Poetry (shir): Poetry was divided in terms of humanistic specializations, i.e. the poetry of law, the poetry of theology, the poetry of philosophy, etc.

3) Rhetoric: epistolography, oratory, and speechmaking

- Epistolography (tarassul)

- Official (sultaniyat)

- Private (ikhwaniyat)

- Oratory (Khataba): Religious preaching and sermon writing

- Speechmaking (Khataba waz): academic and public speeches

4) History (tarikh akhbar): History would include annals, biographies, memoirs, chronicles, and historical novels.

5) Moral Philosophy (ilm al-aklag): Moral philosophy would include such works as Abu Ali al-Husayn ibn AbdAllah ibn Sina, Avicenna's Books of Piety and Sin,
Kitab al-barr wal-ithm, and the works of Ibn Rashd, etc [3].

Those engaging in a humanistic education were divided among three categories: amateurs, professions, and notaries. Amateurs were grouped to include jurists, physicians, philosophers, theologians, astronomers, astrologers, and mathematicians. Professionals were grouped to include chancellors, secretaries of all ranks from heads of state to mere clerks, and tutors. Notaries belonged in both groups: "as a lawyer they were amateur humanists and as a composer of formal documents they were considered professional humanists" [3]. Arabic books on classical Islamic humanism were in abundance in southern Italy and Spain, as secretaries in these regions were, by nature of the demands of office, multilingual in Latin, Arabic, Greek, and the vernacular of the languages of the region.

The ars dictaminis provided a strong component to the humanistic education of medieval times in the Christian West; however, its origins have remained somewhat of a mystery to scholars, and some contend its origins are to be found in Classical Islamic education. The ars dictaminis was a descriptive guidebook on the art of prose composition, primarily in epistolary form. The art of letter writing, as it has been termed, was associated with education in the law since letters could serve as important legal documents; furthermore, teachers of the ars dictaminis occasionally gave instruction in forensic speaking [2].

The term ars dictaminis is derived from the Latin verb "dictare" the technical meaning of which is "to write what is said." The ars dictaminis evolved into meaning much more, to include the art of composition, private epistolary correspondence, and the technical rules for the composition and compilation of official legal documents. "Dictamen was a prominent element in a legal education in the days of Irnerius (1100 AD) and dictamen included the art of literary composition as well as the technical art of the notary," according to medieval scholar Hastings Rashdall [11]. The ars dictaminis was implemented into the humanistic curriculum, and it became the established policy of magistrates to evaluate a prospective candidate's proficiency in the area prior to being accepted into the guild of notaries; it was regarded as a basic training course for future members of the notarial profession [11].

The Latin titling of the art of epistolary composition has puzzled many Western scholars because the ars dictaminis, should, by virtue of its title, imply the "art of dictation." Latin, being a specific language, contains words both for composition, compositionis, and letter writing, epistolaris [5]. In classical Islamic humanistic education there existed a very fundamental work of study called literally al-Amali or the "art of dictation." The characteristics of classical Arabic require dictation as opposed to copying the written word given the vowel-less structure of the language; a string of mere consonants is meaningless. The word had to be heard by the speaker:

- The classical Arabic word is thus correctly learned only when the person recording it hears it correctly spoken, and records it correctly with its diacritical points and vowel-signs. The written word is lifeless; the speaker breathes life into the inert consonants, resurrecting them by vocalizing as he speaks. 
Diacritics are used to differentiate between letters of the written word; but vowel signs must also be supplied. And whereas, early on, diacritics came to be supplied in the text, the vowel signs were not. One and the same cluster of consonants fully supplied with diacritics but devoid of vowel-signs can produce a plural noun, an infinitive noun, an active verbal sentence, and a passive verbal sentence all with only a three-letter root word [5].

Makdisi gives a classic elementary schoolboy example in the Arabic language still used to this very day to illustrate the importance of teaching the art of dictation. It regards a simple three letter consonant string, $\mathrm{K}-\mathrm{T}-\mathrm{B}$ :

- $\mathrm{KuTuB}=$ "books" (plural noun)

- $\mathrm{KaTB}=$ "writing" (infinitive noun/gerund)

- $\mathrm{KaTaBa}=$ "He wrote" (active verbal sentence)

- $\mathrm{KuTiBa}=$ "It was written" (passive verbal sentence)

The medieval text by Sam'ani entitled The Art of Dictation and of Taking Diction gives advice to both students and teachers of the art. Imla or "dictation" still forms the backbone of traditional grammar school study of the Arabic language in most of the Middle East. However, Imla is not limited to simple dictation; it is expanded upon to include the basic components of what Western Christendom refers to as the ars dictaminis, that being the art of all that constitutes prose composition, with a particular interest in the epistolary arts both private and public [7].

The art of letter writing in Classical Arabic also evolved to form a prominent aspect in legal communication and documentation, as it developed a connection with the law early on in the history of Islamic jurisprudence. It was initially called ilm ash-shurut wa l-sijillat or the "science of composing legal instruments and keeping official registers"; Hajj Khalifa defines the field of forensic epistolography in the following terms:

- It is a science which seeks ways of documenting in books and registers decisions established in the presence of the qadi in such a way that they may be adduced as evidence when the witness to the actual transactions have died. Some of its principles are taken from law (Fiqh), some from the art of composition (insha), some from legal instruments (rusum), custom (adat), and discretionary legal decisions (umur istihsaniyya). It is a branch of positive law (Fura alfiqh) by reason of the fact that is concepts are arrived at in conformity with the rules of divinely revealed law (shar). It may finally be regarded as a branch of the literary arts from the standpoint of embellishment of wording [4].

\section{CONCLUSION}

The Classical Islamic age shares a great deal of scholarship with the Christian West of the late medieval and early modern ages, yet little emphasis is put on our common roots in scholasticism and Medieval/Renaissance humanism. We share a common ground in elevating eloquence and the dignity of Man. Surely, in these times of unparalleled
East/West discord, the Classical Islamic scholarships of Ibn Rashd and the possible origins of the ars dictaminis deserve more than a cursorily passing remark in our tomes of Classical, Medieval, and Renaissance rhetorical traditions.

Research in the Middle East's contribution to Western thought is slim, spotty, and hard to come by. The Islamic political control spread over much of southern Europe sporadically from $711 \mathrm{AD}$ to $1492 \mathrm{AD}$, and its affects are found in the development of Western thought; we have simply chosen to ignore the exploration of this history. It would shock many scholars to note that the oldest degreegranting university in existence, the University of AlKarabuine or Al-Qarawiyyin, established in 859 AD, was founded by an Arab woman, Fatima al-Fihri [12]. Surely, this is worth at least a footnote on our pages of history. Western intellectual thought needs to investigate the influences brought about by contact with Classical Islamic civilization. As respected medieval scholar George Makdisi asserts, "our religious monotheism is Judeo-Christian, and our intellectual culture is Greco-Roman, what I believe we have yet to realize is that an essential part of our intellectual culture, namely, our university and scholarly culture, is Arabo-Islamic." Awareness of our common cultural history and intellectual interdependence could become the foundation of a much-needed bridge of peace in our modern world.

\section{REFERENCES}

[1] E. Peters, Limits of Thought and Power in Medieval Europe, Hampshire: Ashgate, 2001, pp. 56-197.

[2] P. Bizzell and B. Herzberg, The Rhetorical Tradition: Readings from Classical Times to the Present, Boston: Bedford/St. Martin's, 2001, pp. 444-456.

[3] G. Krotkoff, Humanism, Culture, and Language in the Near East, Winona Lake: Eisenbrauns, 1997, pp. 117-144.

[4] G. Makdisi, The Rise of Colleges: Institutions of Learning in Islam and the West, Edinburgh: Edinburgh University Press, 1981, pp. 256267.

[5] G. Makdisi, "Scholasticism and humanism in classical Islam and the Christian West," Journal of the American Oriental Society, vol. 109, pp. $175-182,1989$.

[6] Aristotle, On Rhetoric, Trans. George Kennedy, Oxford: Oxford University Press, 1991, pp. 19-47.

[7] G. Makdisi, The Rise of Humanism in Classical Islam and the Christian West: With a Special Reference to Scholasticism, Edinburgh: Edinburgh University Press, 1990, pp. 12-265.

[8] I. Qudama, Censure of Speculative Theology, Cambridge: Thetford Press, 1985, pp. 69.

[9] L. Thorndike. (October 1940). Elementary and secondary education in the Middle Ages. Speculum. [Online]. 15(4). pp. 400-408. Available: www.jstor.org/stable/285345

[10] J. Murphy, Rhetoric in the Middle Ages, Berkeley, CA: University of California Press, 1981, pp. 194.

[11] G. Makdisi, Religion, Law, and Education in Classical Islam, Hampshire: Variorum, 1991, pp. 178-189.

[12] A. Basit, The Global Muslim Community at a Crossroads: Understanding Religious Beliefs, Practices, and Infighting to End the Conflict, Santa Barbara, CA: Praeger, 2012, pp. 69.

Rena D. Dossett holds a BA in psychology, MA in linguistics, and $\mathrm{PhD}$ in English /rhetoric (in progress) from Ball State University, Muncie, IN, USA. She has worked extensively in the Middle East region in higher education. She is currently engaged in the final write-up of her dissertation on cross-cultural collaboration, and is a doctoral assistant at Ball State University's Learning Center. This is Ms. Dossett's first publication. 